\title{
Peran Konformitas Teman Sebaya dan Kecerdasan Emosi terhadap Adaptabilitas Karier pada Siswa Kelas XI dan XII SMA Negeri 7 Surakarta
}

\author{
Setiana Tyas Habsari ${ }^{(1)}$, Munawir Yusuf ${ }^{(2)}$, Mahardika Supratiwi ${ }^{(3)}$ \\ ${ }^{(1),(2)}$ Program Studi Psikologi, Universitas Sebelas Maret, Surakarta, Indonesia \\ ${ }^{(3)}$ Program Studi Pendidikan Khusus, Universitas Sebelas Maret, Surakarta, Indonesia \\ The goals of the present work were two-fold. The first was to examine the extent to which peer \\ conformity and emotional intelligence simultaneously explained career adaptability among \\ grade XI and grade XII students in SMA Negeri 7 Surakarta. Participants were 272 students \\ derived from a stratified cluster random sampling. Designed as correlational quantitative \\ research, we found that, first, peer conformity and emotional intelligence significantly and \\ simultaneously explained career adaptability. The second finding showed that peer conformity \\ did not play a significant role in partially explaining career adaptability. The third finding \\ revealed that emotional intelligence significantly and partially explained career adaptability, \\ implying that high levels of emotional intelligence were associated with high levels of career \\ adaptability. In the discussion section, we discuss the theoretical implications of each of those \\ empirical findings, as well as research limitations and suggestions for future research to \\ improve the limitations.
}

Keywords: career adaptability, emotional intelligence, peer conformity

Penelitian ini bertujuan untuk mengetahui peran simultan dan parsial konformitas teman sebaya dan kecerdasan emosi dalam menjelaskan adaptabilitas karier pada siswa kelas XI dan XII SMA Negeri 7 Surakarta. Subjek penelitian adalah 272 siswa yang diperoleh atas dasar stratified cluster random sampling. Penelitian ini didesain sebagai studi kuantitatif korelasional yang menemukan bahwa, pertama, konformitas teman sebaya dan kecerdasan emosi secara simultan atau bersama-sama berperan signifikan dalam menjelaskan adaptabilitas karier. Temuan kedua menunjukkan bahwa konformitas teman sebaya secara parsial tidak berperan signifikan dalam menjelaskan adaptabilitas karier. Temuan ketiga menunjukkan bahwa kecerdasan emosi secara parsial berperan signifikan dalam menjelaskan adaptabilitas karier dimana tingginya kecerdasan emosi berkaitan dengan tingginya adaptabilitas karier. Bagian diskusi dalam tulisan ini menjelaskan implikasi teoritis temuan-temuan penelitian tersebut, disertai dengan sejumlah kelemahan penelitian dan saran perbaikan yang bisa dilakukan pada penelitian lanjutan.

Kata kunci: adaptabilitas karier, kecerdasan emosi, konformitas teman sebaya

MEDIAPSI, 2020, Vol. 6(2), 102-109, DOI: https://doi.org/10.21776/ub.mps.2020.006.02.4

Received: 17-01-2020. Revised: 31-07-2020. Accepted: 18-09-2020. Published online: 07-12-2020

Handling Editor: Ali Mashuri, Universitas Brawijaya, Malang, Indonesia

*Corresponding author: Setiana Tyas Habsari, Program Studi Psikologi, Universitas Sebelas Maret, Surakarta, Indonesia. E-mail: Thabsari26@gmail.com

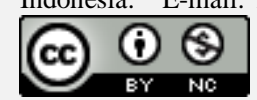

This work is licensed under a Creative Commons Attribution-NonCommercial 4.0 International License.

How to cite this article in accordance with the American Psychological Association (APA) $6^{\text {th }}$ guidelines:

Habsari, S. T., Yusuf, M., \& Supratiwi, M. (2020). Peran konformitas teman sebaya dan kecerdasan emosi terhadap adaptabilitas karier pada siswa Kelas XI dan XII SMA Negeri 7 Surakarta. MEDIAPSI, 6(2), $102-109$. https://doi.org/10.21776/ub.mps.2020.006.02.4

\section{Pendahuluan}

Pendidikan adalah salah satu bagian proses siswa untuk menyiapkan kehidupan karier masing-masing individu. Pendidikan dapat mendukung siswa memenuhi kebutuhan kariernya (Sharma, Kim \& Bryan, 2017). Karier 
menjadi bagian yang berpengaruh bagi kebahagiaan individu secara keseluruhan, yang menentukan keberhasilan individu di masa depan. Santrock (2003) mengemukakan bahwa sebesar 50\% remaja mengalami kebingungan dalam memilih karier. Remaja sering mengalami kebingungan, ketidakpastian, bahkan stres dalam mengambil keputusan terkait karier mereka.

Setiap individu membuat pilihan karier di kehidupan yang dapat menentukan pekerjaan mereka di masa depan. Remaja yang memasuki tahap usia 17 tahun dan 18 tahun diharapkan mampu mengambil keputusan karier yang sudah ditetapkan tanpa keraguan. Namun, apabila remaja dihadapkan pada kebingungan dan pikiran yang berubah-ubah maka dapat dinyatakan bahwa mereka mengalami keraguan dalam memilih karier (Gutman \& Schoon, 2012; Hurrelmann, Engel, \& Weidman, 1992).

Masa pencarian karier menjadi masa sulit bagi sejumlah remaja karena tidak semua remaja mampu mengambil keputusan dengan mudah. Terkadang remaja merasakan kecemasan dan tekanan yang disebabkan karena mereka belum matang dalam menyelesaikan tugas perkembangan karier (Creed, Patton, \& Prideaux, 2006). Menurut Educational Psychologist dari Intergrity Development Felxibility (Amalia \& Erawan, 2017), tercatat sebanyak $87 \%$ mahasiswa di Indonesia merasa kesulitan dalam memilih jurusan. Kesulitan ini akan berdampak pada ketidakoptimalan pada pekerjaan atau profesi yang akan digeluti sehingga siswa tidak dapat berprestasi dan keterampilan yang mereka miliki tidak berkembang dengan baik (Awaliyah, 2019).

Dalam suatu pilot study tahun 2019 di SMA Negeri 7 Surakarta, peneliti menemukan bahwa sebanyak 41 siswa menyatakan kebimbangan dalam menentukan arah karier mereka. Sebagai rincian, sebanyak $65 \%$ siswa menyatakan dirinya telah mempersiapkan karier masa depan tetapi mengalami keraguan dalam menetapkan karier. Sebagian dari siswa juga belum mengetahui atau menyadari tujuan karier yang jelas, serta malas mencari informasi karier. Selain itu, sebagian dari mereka merasa kurang cocok dengan jurusan yang mereka pilih, kesulitan dalam mengerjakan tugas, dan kurang puas dengan fasilitas sekolah sebagai penunjang karier mereka.

Suatu keadaan yang memungkinkan remaja berhasil mengatasi persoalan-persoalan karier ialah mencapai adaptabilitas karier. Savickas dan Porfeli (2012) menyatakan bahwa adaptabilitas karier adalah kesiapan untuk menyiapkan tugas karier secara tepat. Dengan adaptabilitas karier yang memadai, individu mampu membentuk perilaku adaptif untuk menyelesaikan dan menguasai tugas perkembangan kariernya (Sisca \& Gunawan, 2016).

Setiap remaja SMA mempunyai kesempatan meraih karier sesuai dengan keinginan dan kemampuannya. Kesempatan ini tentunya tidak dapat diperoleh tanpa adanya persiapan yang matang. Mencapai karier seringkali disertai dengan berbagai hambatan, dan hambatan ini sangat sering dialami oleh remaja SMA. Oleh karena itu, remaja SMA harus mampu menggali informasi terkait karier, yang salah satunya bisa dilakukan melalui teman sebaya (Hendayani \& Abdullah, 2018). Cronk, Schuster dan Ashburn (dalam Listyowati, Andayani \& Karyanta, 2012) mengungkapkan bahwa remaja lebih banyak menghabiskan waktu bersama dengan teman sebaya mereka dibandingkan dengan keluarga. Bersama teman sebaya, remaja belajar mengenai harapan, pembentukan identitas diri, bereksperimen dengan peran tingkah laku dalam satu kelompok, serta melakukan konformitas.

Santrock (2007) menjelaskan bahwa konformitas mencerminkan pengadopsian sikap atau perilaku dikarenakan tekanan dari orang lain. Selanjutmya, Hurlock dan Elizabeth (1994) menambahkan bahwa konformitas sebagai bentuk kebutuhan remaja untuk diterima di lingkup pertemanan sebaya sehingga remaja melakukan perubahan sikap 
dan perilaku sesuai dengan norma anggota kelompok teman sebaya. Sementara itu, Baron dan Byrne (2005) mengartikan konformitas sebagai suatu jenis pengaruh sosial kelompok dimana individu mengubah sikap dan tingkah laku mereka agar sesuai dengan norma sosial yang berlaku.

Penelitian Alamiarti (2015) di SMK

Karya Rini YHI Kowani di Kabupaten Sleman, Yogyakarta, menunjukkan bahwa tingkat konformitas berkontribusi sebesar $41.3 \%$ terhadap pengambilan karier. Hasil ini memberikan implikasi bahwa konformitas pada teman sebaya dapat memicu pengambilan keputusan karier serta arah tujuan karier siswa yang jelas. Selain itu, saran yang diberikan oleh teman sebaya dapat memberikan sumbangan terhadap keputusan karier yang dipilih oleh remaja SMA. Kenny dan Bledsoe (2015) menemukan bahwa konformitas berkontribusi secara signifikan dalam menjelaskan adaptabilitas karier karena remaja berkeinginan untuk mendapatkan penerimaan dan afirmasi dari teman sebaya. Zulfani (2017) menambahkan bahwa remaja SMA sering mengikuti teman dalam menentukan pilihan karier di berbagai jenis sekolah yaitu SMA, MA maupun SMK.

Penentuan karier siswa tidak hanya dipengaruhi oleh kemampuan dan kemauan diri, tetapi dipengaruhi juga oleh pengaturan emosi (Purwanta, 2012). Individu dengan kemampuan mengatur emosi terkait dengan pengaturan rencana dan tindakan tentang karier mencerminkan individu yang memiliki kecerdasan emosi yang memadai. Kecerdasan emosi ini juga berperan dalam memprediksi adaptabilitas karier (Coetzee \& Harry, 2014). Fabio, Palazzeschi, Asulin-Peretz, dan Gati (2013) menambahkan, individu dengan kecerdasan emosi tinggi merasa yakin dengan pilihan karier mereka.

Menurut Salovey dan Mayer (1990), kecerdasan emosi merupakan bagian dari kecerdasan sosial yang melibatkan kemampuan untuk memantau perasaan dan emosi seseorang dan orang lain serta memilah dan menggunakan informasi tersebut untuk membimbing pikiran dan tindakan.

Hasil penelitian Fabio dan Kenny (2015) pada 254 siswa sekolah menengah di Italia menunjukkan bahwa kecerdasan emosi berkontribusi dalam memprediksi kemajuan adaptabilitas karier siswa. Selanjutnya, penelitian oleh Suban (2016) di SMA Kristen 2 Binsus Tumohon menunjukkan bahwa kecerdasan emosi berkontribusi terhadap pengambilan keputusan karier dengan persentase sebesar $15.84 \%$. Hasil ini bermakna bahwa semakin tinggi kecerdasan emosi berimplikasi pada semakin tinggi pengambilan keputusan karier siswa.

Berdasarkan pemaparan teori dan temuan-temuan empiris yang terkait sebagaimana dikemukan di atas, penelitian ini mengajukan tiga hipotesis:

1. Konformitas teman sebaya dan kecerdasan emosi secara simultan atau bersama-sama berperan signifikan dalam menjelaskan adaptabilitas karier siswa SMA Negeri 7 Surakarta (Hipotesis 1).

2. Konformitas teman sebaya secara parsial berperan signifikan dalam menjelaskan adaptabilitas karier pada siswa SMA Negeri 7 Surakarta (Hipotesis 2).

3. Kecerdasan emosi secara parsial berperan signifikan dalam menjelaskan adaptabilitas karier pada siswa SMA Negeri 7 Surakarta (Hipotesis 3).

\section{Partisipan dan desain penelitian}

Populasi pada penelitian ini yaitu siswa kelas XI dan XII SMA Negeri 7 Surakarta dengan jumlah 683 siswa. Sesuai dengan penggunaan rumus Slovin maka diperoleh hasil ukuran sampel subjek penelitian sebanyak 272 siswa.

Teknik pengambilan sampel ini menggunakan stratified cluster random sampling dengan rincian 34 siswa kelas XI IPA VI, 34 siswa kelas XI IPA II, 34 siswa kelas XI 
IPS III, 33 siswa kelas XI IPS 1, 34 siswa kelas XII IP A 1, 34 siswa kelas XII IPA II, 36 siswa kelas XI IPS VI dan 33 siswa kelas XII IPS 4. Sehingga, total sampel subjek penelitian ini sejumlah 272 siswa.

Penelitian ini menggunakan pendekatan kuantitatif korelasional dengan mengukur melalui suatu skala masing-masing variabel penelitian. Variabel-variabel dalam penelitian ini terdiri dari konformitas teman sebaya sebagai variabel independen pertama (X1), kecerdasan emosi sebagai variabel independen kedua (X2), dan adaptabilitas karier sebagai variabel dependen $(\mathrm{Y})$.

\section{Prosedur dan pengukuran}

Skala pertama dalam penelitian ini bertujuan untuk mengukur adaptabilitas karier, yang diadaptasi dari the Career Adaptabilities Scale (CAAS; Porfeli \& Savickas, 2012). Konstruk adaptabilitas karier dalam skala tersebut terdiri dari aspek kepedulian karier, pengendalian karier, keingintahuan karier, dan keyakinan karier

Skala kedua bertujuan untuk mengukur konformitas teman sebaya, yang disusun oleh peneliti dengan acuan aspek-aspek yang diungkap oleh Baron dan Bryne (2005). Aspekaspek ini meliputi konformitas normatif dan konformitas informatif.

Skala ketiga bertujuan untuk mengukur kecerdasan emosi, yang diadaptasi dari Utama (2017). Mengacu pada Salovey dan Mayer (1990), skala ini terdiri dari beberapa aspek, yang meliputi pengenalan emosi diri, pengelolaan emosi diri, motivasi diri, pengenalan emosi orang lain, dan kemampuan membina hubungan sosial.

\section{Hasil}

Menggunakan SPSS 25, hipotesishipotesis dalam penelitian ini diuji menggunakan teknik regresi berganda (Arikunto, 2013).

Hasil analisis menunjukkan bahwa, pertama, efek simultan konformitas teman sebaya dan kecerdasan terhadap adaptabilitas karier adalah signifikan, $F(2,270)=49.56, p<$ .001. Hasil ini mendukung Hipotesis 1 dan menunjukkan peran simultan konformitas teman sebaya dan kecerdasan emosi terhadap adaptabilitas karier pada siswa kelas XI dan XII SMA Negeri 7 Surakarta adalah signifikan.

Tabel 1. Hasil Uji Korelasi Parsial antara Konformitas Teman Sebaya, Kecerdasan Emosi, dan Adaptabilitas Karier

\begin{tabular}{|c|c|c|c|c|}
\hline & Variabel & 1) & 2) & 3) \\
\hline 1) & $\begin{array}{l}\text { Konformitas } \\
\text { teman sebaya }\end{array}$ & & - & $-.08^{n s}$ \\
\hline 2) & $\begin{array}{l}\text { Kecerdasan } \\
\text { emosi }\end{array}$ & & & $.51 * * *$ \\
\hline 3) & $\begin{array}{l}\text { Adaptabilitas } \\
\text { karier }\end{array}$ & & & - \\
\hline
\end{tabular}

Sementara itu, Hipotesis 2 dan Hipotesis 3 dibuktikan atas dasar uji korelasi parsial sebagai bagian dari hasil uji regresi berganda. Hasil analisis ini ditampilkan pada Tabel 1. Sebagaimana bisa dilihat pada Tabel 1, hasil menunjukkan bahwa konformitas teman sebaya secara parsial tidak berperan signifikan dalam menjelaskan adaptabilitas karier. Hipotesis 2 dalam penelitian ini dengan demikian ditolak.

Selanjutnya, kecerdasan emosi ditemukan berperan signifikan secara parsial dalam menjelaskan adaptabilitas karier. Prosentase peran kecerdasan emosi dalam menjelaskan adaptabilitas karier adalah sebesar $26 \%$, yang dihitung dengan mengkuadratkan koefisien korelasi parsial. Dengan hasil ini, Hipotesis 3 dalam penelitian ini diterima.

\section{Diskusi}

Penelitian ini bertujuan untuk menguji peran simultan dan peran parsial konformitas teman sebaya dan kecerdasan emosi dalam memprediksi atau menjelaskan adaptabilitas karier. Dalam penilitian ini, tingginya kecerdasan emosi berperan signifikan dalam memprediksi tingginya adaptabilitas karier. Hasil ini sejalan dengan hasil penelitian Fabio 
dkk. (2013) yang menunjukkan peran signifikan tingginya kecerdasan emosi yang dimiliki individu sebagai prediktor kemantapan individu dalam menata karier. Kemantapan ini mampu mendukung tahapan karier individu masingmasing serta menawarkan berbagai peluang sarana untuk pertumbuhan karier kepada teman sebaya lainnya (Felsman \& Blustein, 1999; Kram \& Isabella, 1985).

Tingginya kecerdasan emosional pada individu akan diikuti dengan tingginya kematangan karier (Rahardjo \& Lestari, 2013). Individu dengan kecerdasan emosi tinggi akan mudah melakukan pengambilan keputusan karena tidak cenderung terbawa emosi negatif yang mengganggu pikiran dan membuat individu mudah tersinggung (Drastiana, 2016).

Kecerdasan emosi juga mempengaruhi salah satu aspek dari adaptabilitas karier yaitu kepercayaan diri (confidence). Kepercayaan diri ini memberdayakan remaja untuk mampu mengatasi dan melewati hambatan karier melalui keyakinan diri dalam menghadapi kesulitan-kesulitan (Nugraheni, Wibowo, \& Murthado, 2017).

Sementara itu, penelitian ini juga menunjukkan bahwa konformitas teman sebaya secara parsial tidak berperan signifikan dalam menjelaskan adaptabilitas karier. Temuan ini mengandung makna bahwa dengan mengendalikan pengaruh kecerdasan emosi, peran konformitas teman sebaya menjadi inferior dalam menjelaskan adaptabilitas karier pada siswa SMA. Kracke (2002) menyatakan bahwa eksplorasi karier yang dilakukan di dalam sebuah kelompok kerja teman sebaya tidak efektif khususnya apabila terdapat kehadiran teman sebaya yang berpotensi sebagai pengganggu di dalam kelompok tersebut. Selain itu, hasil tersebut menegaskan bahwa kecerdasan emosi memang berperan sebagai prediktor positif adaptabilitas karier dengan mengendalikan faktor faktor lain (LaGree, Tefertiller, \& Olsen, 2020; Rudolph, Lavigne, \& Zacher, 2017).
Penelitian ini mengandung sejumlah kelemahan, yang bisa diperbaiki pada studistudi lanjutan. Kelemahan pertama terkait dengan banyaknya faktor selain konformitas teman sebaya dan kecerdasan emosi yang mempengaruhi adaptabilitas karier. Studi berikutnya dengan demikian bisa menguji peran faktor-faktor tersebut, seperti demografi (usia dan tingkat pendidikan) dan kepribadian (contoh: kepribadian proaktif; Rudolph dkk., 2017), serta faktor situasional seperti tingkat dukungan sosial (Hirschi, 2009).

Kelemahan kedua terkait dengan keterbasan sampel dalam penelitian yang hanya terfokus pada siswa SMA. Generalisasi hasil dalam penelitian ini dengan demikian perlu diuji pada studi-studi berikutnya dengan menggunakan sampel yang lebih bervariasi. Sampel alternatif ini misalnya adalah mahasiswa dan pekerja. Penelitian-penelitian sebelumnya menemukan bahwa di kalangan mahasiswa (Celik \& Storme, 2018) dan pekerja (Coetzee \& Harry, 2014), kecerdasan emosi juga berperan signifikan sebagai prediktor positif adaptabilitas karier.

\section{Daftar Pustaka}

Alamiarti, K. A. (2015). Hubungan antara konformitas teman sebaya dan harga diri dengan pengambilan keputusan karir pada siswa kelas XII SMA Karya Rini YHI Kowani Yogyakarta. Jurnal Riset Mahasiswa Bimbingan Dan Konseling, 4(5), 1-15. Diakses dari http://journal.student.uny.ac.id/ojs/inde x.php/fipbk/article/view/230/211

Amalia, M. D., \& Erawan. L. (2017). Penerapan algoritma apriori untuk membantu calon mahasiswa dalam memilih program studi di fakultas ilmu komputer Universitas Dian Nuswantoro. Joins, 2(2), 207-212. https://doi.org/10.33633/joins.v2i2.167 7 
Arikunto, S. (2013). Prosedur penelitian: Suatu pendekatan praktik. Jakarta: Rineka Cipta.

Awaliyah, G. (2019, Februari 7). Survei: 87 persen mahasiswa mengaku salah pilih jurusan. Republika. Diakses dari https://republika.co.id/berita/pendidika n/dunia-kampus/pmjuhw368/87persen-mahasiswa-mengaku-salahpilih-jurusan

Baron, R, A \& Byrne, D. (2005). Psikologi sosial. Jakarta: Erlangga.

Celik, P., \& Storme, M. (2018). Trait emotional intelligence predicts academic satisfaction through career adaptability. Journal of Career Assessment, 26(4), 666-677. https://doi.org/10.1177\%2F10690727177 23290

Coetzee, M., \& Harry, N. (2014). Emotional inteligence as a predictor of employees's career adaptability. Journal Vocational Behaviour, 84(1), 90-97.

https://doi.org/10.1016/j.jvb.2013.09.0 01

Creed, P., Patton, W., \& Prideaux, L.-A. (2006). Causal relationship between career indecision and career decisionmaking self-efficacy: A longitudinal cross-lagged analysis. Journal of Career Development, 33(1), 47-65. https://doi.org/10.1177\%2F089484530 6289535

Drastiana, E. (2016). Hubungan antara kecerdasan emosi dengan pengambilan keputusan karier pada remaja. (Tesis, Fakultas Psikologi Universitas Negeri Malang, Malang, Indonesia). Diakses dari http://eprints.umm.ac.id/34377/

Fabio, A. D., Palazzeschi, L., Asulin-Peretz, L., \& Gati, I. (2013). Career indecision versus indecisiveness: Associations with personality traits and emotional intelligence. Journal of Career Assessment, 21(1), $42-56$
https://doi.org/10.1177\%2F106907271 2454698

Fabio, A., \& Kenny, M. E. (2015). The contributions of emotional intelligence and social support for adaptive career progress among Italian youth. Journal of Career Development, 42(1), 48-59. https://doi.org/10.1177\%2F089484531 4533420

Felsman, D. E., \& Blustein, D. L. (1999). The role of peer relatedness in late adolescent career development. Journal of Vocational Behavior, 54(2), 279-295. https://doi.org/10.1006/jvbe.1998.1664

Gutman, L. M., \& Schoon, I. (2012). Correlates and consequences of uncertainty in career aspirations: Gender differences among adolescents in England. Journal of Vocational Behavior, 80(3), 608-618. https://doi.org/10.1016/j.jvb.2012.02.0 02

Hendayani, N., \& Abdullah, S. M. (2018). Dukungan teman sebaya dan kematangan karier mahasiswa tingkat akhir. Jurnal Ilmiah Psikologi Terapan, 6(1), 28-40. https://doi.org/10.22219/jipt.v6i1.5189

Hirschi, A., Niles, S. G., \& Akos, P. (2011). Engagement in adolescent career preparation: Social support, personality and the development of choice decidedness and congruence. Journal of Adolescence, $\quad 34(1), \quad$ 173-182. https://doi.org/10.1016/j.adolescence.200 9.12.009

Hurlock, \& Elizabeth .B. (1994). Psikologi perkembangan: Suatu pendekatan sepanjang rentang Kehidupan. Jakarta: Erlangga.

Hurrelmann, K., Engel, U., \& Weidman, J. C. (1992). Impacts of school pressure, conflict with parents, and career uncertainty on adolescent stress in the Federal

Republic

of 
Germany. International Journal of Adolescence and Youth, 4(1), 33-50. https://doi.org/10.1080/02673843.1992 .9747722

Kenny, M. E., \& Bledsoe, M. (2005). Contributions of the relational context to career adaptability among urban adolescents. Journal of Vocational Behavior, 66(2), 257-272. https://doi.org/10.1016/j.jvb.2004.10.0 02

Kracke, B. (2002). The role of personality, parents, and peers in adolescents career exploration. Journal of Adolescene. 25, 19-30. DOI: 10.1006/jado.2001.0446

Kram, K. E., \& Isabella, L. A. (1985). Mentoring alternatives: The role of peer relationships in career development. Academy of Management Journal, 28(1), 110-132. https://doi.org/10.2307/256064

LaGree, D., Tefertiller, A., \& Olsen, K. (2020). Preparing mass communications students for an evolving industry: The influence of emotional intelligence and extracurricular involvement on career adaptability. Journalism \& Mass Communication Educator. Advance online publication. https://doi.org/10.1177\%2F10776958209 24303

Listyowati, A., Andayani, T. R., \& Karyanta, N. A. (2012). Hubungan antara kebutuhan aktualisasi diri dan dukungan sosial dengan kematangan karier pada siswa kelas XII SMA N 2 Klaten. Jurnal Wacana, 4(8), 119, 116-145.

https://doi.org/10.13057/wacana.v4i2.2 3

Nugraheni, E. P., Wibowo, M. E., \& Murtadho, A. (2017). Hubungan kecerdasan emosional dengan prestasi belajar: Analisis mediasi adaptabilitas karier pada prestasi belajar. Jurnal
Bimbingan Konseling, 6(2), 127-134. DOI 10.15294/JUBK.V6I2.21665

Porfeli, E. J., \& Savickas, M. L. (2012). Career ADAPT-ABILITIES SCALE-USA Form: Psychometric properties and relation to vocational identity. Journal of Vocational Behavior, 80(3), 748753.

https://doi.org/10.1016/j.jvb.2012.01.0 09

Purwanta, E. (2012). Upaya meningkatkan eksplorasi karier anak berkebutuhan khusus. PSIKOPEDAGOGIA Jurnal Bimbingan dan Konseling, 1(2), 1-9. http://dx.doi.org/10.12928/psikopedag ogia.v1i2.2462

Rahardjo, P., \& Lestari. (2013).Hubungan antara kecerdasan emosional dengan kematangan karir pada mahasiswa Universitas Muhammadiyah Purwokerto yang sedang menemupuh Skripsi .Psycho Idea, 11(2), 1-9. http://dx.doi.org/10.30595/psychoidea. v11i2.508

Rudolph, C. W., Lavigne, K. N., Katz, I. M., \& Zacher, H. (2017). Linking dimensions of career adaptability to adaptation results: A meta-analysis. Journal of Vocational Behavior, 102, 151-173. https://doi.org/10.1016/j.jvb.2017.06.003

Salovey, P., \& Mayer, J. D. (1990). Emotional intelligence. Imagination, Cognition, and Personality, 9(3), 185-211. https://doi.org/10.2190\%2FDUGGP24E-52WK-6CDG

Santrock, J.W. (2003). Live span development (Perkembangan masa hidup). (Edisi 51; Alih Bahasa: Chausairi). Jakarta: Erlangga.

Santrock, J. W. (2007). Perkembangan anak (Jilid 1, Edisi kesebelas). Jakarta: PT. Erlangga.

Savickas, M. L., \& Porfeli, E. J. (2012). Career adapt-abilities scale: Construction, reliability, and measurement equivalence across 13 countries. 
Journal of Vocational Behavior, 80(3), 661-673.

https://doi.org/10.1016/j.jvb.2012.01.0

11

Sharma, G., Kim, J., \& Bryan, J. (2017). The effects of purpose orientations on recent high school graduates' college application decisions. Journal of College Access, 3(2), 98-117. Diakses dari https://eric.ed.gov/?id=EJ1167465.

Sisca, S., \& Gunawan, W. (2016). Gambaran adaptabilitas karier remaja. Jurnal Psikologi, 11(2), 111-119. http://dx.doi.org/10.24014/jp.v11i2.14 02

Suban, V. J. (2016). Hubungan antara kecerdasan emosional dan pengambilan keputusan karier pada siswa Kelas X dan XI SMA Kristen 2 Binsus Tomohon (Skripsi, Universitas Karya Satya Wacana. Salatiga, Indonesia). Diakses dari http://repository.uksw.edu/bitstream/1 23456789/10178/2/T1_802012079_Fu $11 \% 20$ text.pdf

Utama, A. B. S. (2017). Hubungan antara kecerdasan emosi dengan penyesuaian diri di perguruan tinggi pada mahasiswa tahun pertama (Skripsi, Universitas Sanata Dharma Yogyakarta, Yogyakarta, Indonesia). Diakses dari https://repository.usd.ac.id/13082/2/12 9114091_full.pdf

Zulfiani, H. (2017). Adaptabilitas karier ditinjau dari dukungan keluarga, jenis kelamin, dan jenis sekolah (Skripsi, Universitas Islam Sunan Kalijaga, Yogyakarta, Indonesia). Diakses dari: http://digilib.uinsuka.ac.id/24558/2/13710017_BABI_IV-atau-V_DAFTARPUSTAKA.pdf 